\title{
KEWIRAUSAHAAN, INOVASI TEKNOLOGI, DAN KEUNGGULAN BERSAING PADA USAHA MIKRO, KECIL, DAN MENENGAH (UMKM) MAKANAN DI KECAMATAN CIBINONG
}

\author{
Luhung Bagas Prayogo', Suharyati ${ }^{2}$, M.B Nani Ariani ${ }^{3}$ \\ 1,2,3 Universitas Pembangunan Nasional "Veteran" Jakarta \\ Email: Iprayogo20@gmail.com, yatididi01@gmail.com, nani.upnvj@gmail.com
}

\section{KETERANGAN ARTIKEL}

Riwayat Artikel

Diterima: 24 November 2019

Direvisi: 10 Desember 2019

Disetujui: 28 Desember 2019

\section{Klasifikasi JEL}

$\mathrm{M} 2, \mathrm{M} 21$

Keywords: entrepreneurship, technological innovation, competitive advantage

Kata kunci: kewirausahaan, inovasi teknologi, keunggulan kompetitif

\section{ABSTRACT}

This research is a quantitative research that aims to determine the effect of entrepreneurship and technological innovation on the competitive advantage of food MSMEs in Cibinong Subdistrict. The population used for this research is the businessmen MSMEs food entreprises at Cibinong Subdistrict. The number of sample which is taken was 50 respondents. The sampling technique for this research is purposive sampling method. The analysis technique used is Partial Least Square with 5\% significance. The results of the testing are obtained (1) there is a significant effect of entrepreneurship on competitive advantage, (2) there is a significant influence of technological innovation on competitive advantage

\section{ABSTRAK}

Penelitian ini adalah penelitian kuantitatif yang bertujuan untuk mengetahui pengaruh kewirausahaan dan inovasi teknologi terhadap keunggulan bersaing Usaha Mikro, Kecil, dan Menengah (UMKM) makanan di Kecamatan Cibinong. Populasi yang digunakan untuk penelitian ini adalah pelaku UMKM makanan di Kecamatan Cibinong. Jumlah sampel yang diambil adalah 50 responden. Teknik pengambilan sampel untuk penelitian ini menggunakan metode purposive sampling. Teknik analisis yang digunakan adalah Partial Least Square dengan signifikansi 5\%. Hasil pengujian diperoleh (1) terdapat pengaruh kewirausahaan yang signifikan terhadap keunggulan bersaing, (2) terdapat pengaruh inovasi teknologi yang signifikan terhadap keunggulan bersaing.

\section{PENDAHULUAN}

Pertumbuhan ekonomi pada suatu wilayah menunjukkan proses perubahan kondisi perekonomian menuju keadaan yang lebih baik. Berdasarkan Badan Pusat Statistik
(BPS) Kabupaten Bogor, mencatat bahwa pertumbuhan ekonomi di Kabupaten Bogor mengalami kenaikan setiap tahunnya. Hal tersebut dapat dilihat pada grafik di bawah ini. 
Luhung Bagas Prayogo: Pengaruh Kewirausahaan ...

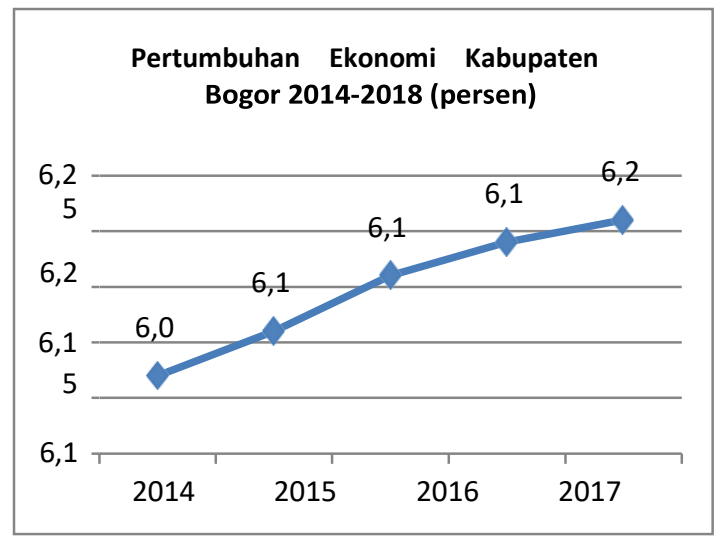

Gambar 1. Grafik Pertumbuhan Ekonomi Kabupaten Bogor 2014 s/d 2018

Sumber: Badan Pusat Statistik Kabupaten Bogor, data diolah

Dari Gambar 1 menandakan perekonomian di Kabupaten Bogor semakin membaik setiap tahunnya. Pertumbuhan perekonomian pada Kabupaten Bogor salah satunya disumbangkan oleh sektor UMKM, dengan kontribusi sebesar 28,45 persen terhadap Produk Domestik Regional Bruto (PDRB) (megapolitan.antaranews.com, 2019). Usaha Mikro, Kecil, dan Menengah (UMKM) merupakan salah satu industri yang dapat berkembang dan konsisten dalam perekonomian nasional. UMKM menjadi wadah yang baik bagi penciptaan lapangan pekerjaan yang produktif. UMKM merupakan usaha yang tidak membutuhkan persyaratan tertentu seperti tingkat pendidikan, keahlian (keterampilan) pekerja, dan penggunaan modal usaha relatif sedikit serta teknologi yang digunakan cenderung sederhana.

Berikut ini merupakan grafik mengenai pertumbuhan jumlah UMKM yang ada di Kabupaten Bogor pada tahun 2014 s/d 2018:

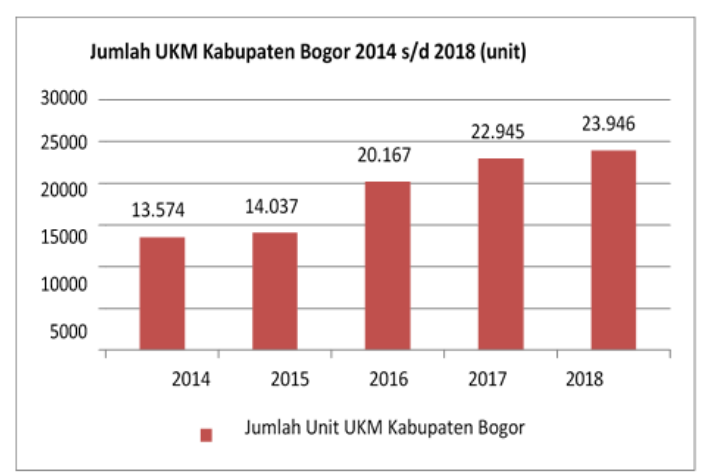

Gambar 2. Grafik Jumlah UMKM Kabupaten Bogor 2014 s/d 2018

Sumber: dinas koperasi dan UMKM kabupaten bogor, data diolah

Berdasarkan data grafik yang dihimpun dari Dinas Koperasi dan UMKM Kabupaten Bogor tahun 2014 s/d 2018, dapat diketahui bahwa jumlah UMKM di Kabupaten Bogor setiap tahunnya selalu meningkat. Pada tahun 2014 jumlah UMKM di Kabupaten Bogor sebesar 13.574 unit usaha, pada tahun 2015 mengalami peningkatan sebesar 463 unit usaha menjadi 14.037 unit usaha, pada tahun 2016 mengalami peningkatan sebesar 6.130 unit usaha menjadi 20.167 unit usaha, pada tahun 2017 mengalami peningkatan sebesar 2.778 unit usaha menjadi 22.945 unit usaha, pada tahun 2018 mengalami peningkatan sebesar 1.001 unit usaha menjadi 23.946 unit usaha. Salah satu Kecamatan yang mengalami peningkatan jumlah UMKM di Kabupaten Bogor adalah Kecamatan Cibinong, berikut ini merupakan grafik jumlah UMKM Kecamatan Cibinong periode 2014 s/d 2018: 


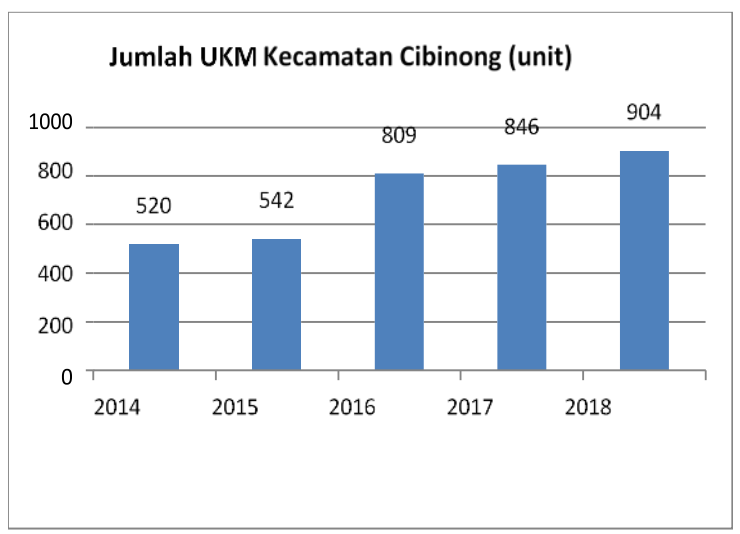

Gambar 3. Grafik Jumlah UMKM Kecamatan Cibinong 2014 s/d 2018

Sumber: dinas koperasi dan umkm kabupaten bogor, data diolah

Berdasarkan data Dinas Koperasi dan UMKM Kabupaten Bogor terlihat jumlah UMKM di Kecamatan Cibinong setiap tahunnya mengalami peningkatan. Pada tahun 2014 jumlah UMKM di Kecamatan Cibinong sebanyak 520 unit usaha, pada tahun 2015 meningkat 22 unit usaha menjadi 542 unit usaha, pada tahun 2016 meningkat 267 unit usaha menjadi 809 unit usaha, pada tahun 2017 meningkat 37 unit usaha menjadi 846 unit usaha, pada tahun 2018 meningkat 58 unit usaha menjadi 904 unit usaha.

Jumlah UMKM yang terus meningkat mengakibatkan persaingan antar pelaku usaha semakin kompetitif. Hal tersebut terjadi karena adanya kesadaran masyarakat tentang berwirausaha. Para pelaku UMKM dituntut untuk memiliki strategi yang mampu menangkap peluang dan lebih inovatif dalam menciptakan serta memasarkan produknya. Dengan semakin berkembangnya suatu bidang usaha maka akan banyak usaha sejenis yang bermunculan, hal ini juga terjadi pada industri makanan dan minuman yang mengakibatkan persaingan bisnis yang semakin kompetitif. Setiap pelaku bisnis pasti memiliki strategi yang berbeda dalam mencapai keunggulan bersaing. Keunggulan bersaing merupakan penciptaan sistem yang mempunyai keunggulan untuk memenangkan persaingan. Keinginan berwirausaha biasanya muncul karena kegemaran terhadap jenis usaha, memiliki impian personal, serta keinginan untuk meningkatkan pendapatan.

Kewirausahaan adalah suatu usaha memenangkan persaingan dengan cara meningkatkan keunggulan dari hasil penciptaan nilai tambah dengan mengkombinasikan sumber daya-sumber daya yang ada melalui suatu cara yang baru dan berbeda dari yang sebelumnya.

Selain kewirausahaan ada faktor lain yang dapat mempengaruhi keunggulan bersaing salah satunya adalah inovasi teknologi. Inovasi teknologi merupakan inovasi yang dilakukan oleh pelaku usaha dengan menyesuaikan terhadap adanya perubahan teknologi yang terjadi dalam lingkungan bisnis. Inovasi ini umumnya terjadi karena adanya penemuan ilmiah dan kemajuan teknologi yang semakin berkembang. Beberapa penelitian telah dilakukan untuk mengetahui pengaruh Kewirausahaan dan Inovasi Teknologi Terhadap Keunggulan Bersaing. Paulus dan Wardhani (2014) dalam penelitiannya menyatakan bahawa ada pengaruh signifikan antara variabel Kewirausahaan dan Inovasi terhadap Keunggulan Bersaing. Hal tersebut sama dengan hasil penelitian dari Muthaher \& Assegaf (2014) dalam penelitiannya menyatakan bahwa variabel inovasi teknologi berpengaruh secara signifikan terhadap keunggulan bersaing. Hal tersebut sama dengan hasil penelitian dari Aziz dan Samad (2015) dalam penelitiannya menyatakan bahwa variabel innovation berpengaruh secara signifikan terhadap competitive advantage. Yuliana, dkk (2016) juga menyatakan bahwa variabel innovation berpengaruh signifikan terhadap competitive advantage. Namun hasil penelitian Djodjobo \& Tawas (2014) dalam penelitiannya menyatakan bahwa variabel Kewirausahaan tidak berpengaruh signifikan terhadap Keunggulan Bersaing. Demikian juga dengan penelitian Chandra, Soegiono, \& 
Sugiarto (2016) dalam penelitiannya menyatakan bahwan variabel Teknologi tidak berpengaruh signifikan terhadap Keunggulan Bersaing.

Berdasarkan fenomena yang telah dijabarkan dan diperkuat dengan adanya gap research dari penelitian terdahulu maka penulis terdorong untuk melihat lebih dalam dan mencoba untuk melakukan kembali penelitian dengan objek dan tempat yang berbeda, yaitu UMKM Makanan yang berada di Kecamatan Cibinong.

\section{KAJIAN LITERATUR DAN PENGEMBANGAN HIPOTESIS \\ Pemasaran}

American Marketing Association dalam Kotler \& Keller (2016) menyatakan bahwa pemasaran adalah kegiatan, serangkaian lembaga dan proses untuk menciptakan, mengkomunikasikan, menyampaikan, bertukar penawaran yang memiliki nilai bagi pelanggan mitra klien, dan masyarakat pada umumnya. Kotler \& Keller (2016) menyatakan bahwa pemasaran adalah tentang mendefinisikan dan memenuhi kebutuhan manusia dan sosial. Salah satu definisi pemasaran terpendek dan terbaik adalah memenuhi kebutuhan secara menguntungkan. Manajemen pemasaran adalah sebagai seni dan sains untuk memilih pasar sasaran dan mendapatkan, memelihara, dan menumbuhkan pelanggan melalui penciptaan, penyampaian dan pengomunikasian nilai pelanggan yang superior.

\section{Usaha Mikro, Kecil, dan Menengah (UMKM)}

Tambunan (2012), Usaha Mikro, Kecil, dan Menengah (UMKM) adalah unit usaha produktif yang berdiri sendiri, yang dilakukan oleh perorangan atau badan usaha di semua sektor ekonomi. Pada prinsipnya, pembedaan antara usaha mikro, usaha kecil, usaha menegah, dan usaha besar umumnya didasarkan pada nilai aset awal (tidak termasuk tanah dan bangunan), omset rata-rata pertahun, atau jumlah pekerja tetap.

\section{Keunggulan Bersaing}

Wilantara \& Susilawati (2016) menyatakan bahwa keunggulan bersaing merupakan hasil dari implementasi strategi yang memanfaatkan berbagai sumber daya yang dimiliki unit usaha. Modal intelektual, khususnya kreativitas merupakan sumber keunggulan bersaing. Hasan (2014) menyatakan bahwa keunggulan bersaing merupakan penciptaan sistem yang mempunyai keunggulan untuk memenang-kan persaingan. Hal ini dicapai untuk menciptakan nilai bagi pelanggan dengan cara efisiensi dan berkelanjutan. Sedangkan menurut Porter dalam Wilantara \& Susilawati (2016) keunggulan bersaing memberikan kontribusi besar untuk perencanaan dan manajemen strategik. Porter berpendapat, bahwa perusahaan yang memiliki keunggulan kompetitif senantiasa memiliki kemampuan dalam memahami perubahan struktur pasar dan mampu memilih strategi pemasaran yang efektif.

\section{Kewirausahaan}

Zakiyudin (2016) menyatakan bahwa kewirausahaan adalah suatu usaha memenangkan persaingan dengan cara meningkatkan keunggulan dari hasil penciptaan nilai tambah dengan mengkombinasikan sumber daya-sumber daya yang ada melalui suatu cara yang baru dan berbeda dari yang sebelumnya. Menurut Suryana \& Bayu (2013) menyatakan bahwa kewirausahaan merupakan semangat, perilaku, dan kemampuan untuk memberikan tanggapan yang positif terhadap peluang memperoleh keuntungan untuk diri sendiri dan/atau pelayanan yang lebih baik pada pelanggan atau masyarakat dengan selalu berusaha mencari dan melayani langganan lebih banyak dan lebih baik, serta menciptakan dan menyediakan produk yang lebih bermanfaat dan menerapkan cara kerja yang lebih efisien melalui keberanian mengambil risiko, kreativitas, dan inovasi. Menurut Robbins \& Coulter menyatakan bahwa (2016) 
menyatakan bahwa kewirausahaan (entrepreneurship) adalah proses memulai bisnis baru, umumnya timbul sebagai respons terhadap peluang. Wirausahawan mengejar peluang dengan mengubah, merevolusi, mentransformasi-kan, atau memperkenalkan produk atau layanan baru.

\section{Inovasi Teknologi}

Anggiani (2018) menyatakan bahwa inovasi merupakan perkembangan ekonomi dari usaha manapun. Ketika teknologi mengalami perubahan, produk-produk lama mengalami penurunan penjualan dan industriindustri lama mengalami pengurangan. Inovasi terjadi bila ide dan kreativitas berhasil menjadi suatu yang bermanfaat baik berupa produk, jasa, atau sistem. Nasution \& Kartajaya (2018) menyatakan bahwa inovasi merupakan kelanjutan dari penemuan (invention) dan kegiatan inovasi merupakan penciptaan nilai (creation of velue) yang melibatkan peningkatan teknologi. Dalam penciptaan nilai tersebut, inovasi harus secara signifikan mampu memberikan nilai tambah kesejahteraan, yang direpresentasikan pada layak jual (diterima pasar) atau tidaknya produk/jasa inovatif tersebut. Suryana (2013) menyatakan bahwa inovasi merupakan kreasi yang lebih baik atau lebih efektif tentang produk, proses, pelayanan, teknologi, atau ideide yang telah tersedia untuk keperluan pasar, pemerintah, dan masyarakat. Sedangkan menurut Anggiani (2018) Inovasi teknologi merupakan inovasi yang dilakukan oleh pelaku usaha dengan menyesuaikan terhadap adanya perubahan teknologi yang terjadi dalam lingkungan bisnis. Inovasi ini umumnya terjadi karen adanya penemuan ilmiah dan kemajuan teknologi yang semakin berkembang.

\section{Hipotesis}

Hipotesis dalam penelitian ini dapat disusun hipotesis sebagai berikut:
H1: Kewirausahaan berpengaruh positif terhadap Keunggulan Bersaing UMKM Makanan.

H2: Inovasi Teknologi berpengaruh positif terhadap Keunggulan Bersaing UMKM Makanan.

\section{METODE PENELITIAN \\ Definisi Operasional}

Definisi operasional variabel penelitian ini adalah:

Kewirausahaan (X1)

Kewirausahaan memiliki pengukuran yang diperoleh atas jawaban responden terhadap kuesioner yang diukur dengan skala likert melalui indikator: keberanian menghadapi risiko, proaktif.

Inovasi Teknologi (X2)

Inovasi Teknologi memiliki pengukuran yang diperoleh atas jawaban responden terhadap kuesioner yang diukur dengan skala likert melalui indikator: pengembangan produk, pengembangan produksi, sistem pengiriman.

\section{Keunggulan Bersaing $(\mathrm{Y})$}

Keunggulan bersaing memiliki pengukuran yang diperoleh atas jawaban responden terhadap kuesioner yang diukur dengan skala likert melalui indikator: harga, kualitas produk, menyenangkan konsumen, keistimewaan layanan, keunikan produk.

\section{Populasi dan Sampel}

Populasi dalam penelitian ini adalah pelaku UMKM di Kecamatan Cibinong. Dalam penelitian ini metode pengambilan sampel yang digunakan adalah teknik nonprobability sampling dengan jenis purposive sampling. Adapun kriteria sampel yang digunakan dalam mengambil sampel yang akan di teliti antara lain: pertama, pelaku usaha UMKM industri makanan ringan. Kedua, lokasi usaha di wilayah Kecamatan Cibinong. Ketiga, usaha sudah beroperasi lebih dari 1 tahun.

Ferdinand (2014) mengatakan bahwa 
ukuran sampel yang lebih besar dari 30 dan kurang dari 500 sudah memadai bagi kebanyakan penelitian. Dalam penelitian multivariate (termasuk yang menggunakan analisis regresi multivariat), besarnya sampel ditentukan sebanyak 25 kali variabel independen.

Berdasarkan ketentuan tersebut, maka besarnya jumlah anggota sampel yang digunakan adalah $25 \times 2=50$ responden. Sehingga jumlah sampel yang diambil adalah 50 responden pelaku usaha makanan di Kecamatan Cibinong.

\section{Teknik Analisis Data dan Uji Hipotesis}

Analisis data pada penelitian ini menggunakan metode partial least square (PLS). Cara Kerja PLS menurut Ghozali (2014,) menyatakan bahwa tujuan PLS adalah membantu penelitian untuk mendapatkan nilai variabel laten untuk tujuan prediksi. Uji Koefisien Regresi Parsial (Uji t), Menurut Ghozali (2016) uji statistik t pada dasarnya menunjukan seberapa jauh pengaruh suatu variabel penjelas/independen secara individual dalam menerangkan variasi dependen. Uji Koefesien Determinasi $\left(R^{2}\right)$, menurut Ghozali (2016) menyatakan bahwa Koefisien determinasi $\left(R^{2}\right)$, pada intinya mengukur seberapa jauh kemampuan variabel bebas dalam menerangkan variasi variabel dependen.

\section{HASIL PENELITIAN DAN PEMBAHASAN Deskripsi Objek Penelitian}

Cibinong merupakan salah satu dari 40 kecamatan yang berada di Kabubupaten Bogor Provinsi Jawa Barat. Kecamatan Cibinong memiliki luas wilayah sebesar 43,36 kilometer persegi, dengan luas wilayah seluas itu Kecamatan Cibinong memiliki 12 kelurahan dan memiliki penduduk berjumlah 427.14 juta jiwa (2017). Kecamatan Cibinong merupakan pusat pemerintahan Kabupaten Bogor. Sebagai pusat pemerintahan, Kecamatan Cibinong memiliki peranan penting dalam pertumbuhan ekonomi di Kabupaten Bogor. Banyak faktor yang mempengaruhi pertumbuhan ekonomi di suatu daerah. Salah satu faktor pendorong pertumbuhan ekonomi di suatu daerah dengan adanya Usaha Mikro Kecil Menengah (UMKM).

Usaha Mikro Kecil Menengah (UMKM) memiliki peranan besar dalam perekonomian rakyat di Kecamatan Cibinong. Keberadaan UMKM selama ini menjadi sumber nafkah masyarakat dan mampu menyerap banyak tenaga kerja hal tersebut sekaligus mengurangi jumlah pengangguran di Kecamatan Cibinong. UMKM merupakan usaha yang tidak membutuhkan persyaratan tertentu seperti tingkat pendidikan, keahlian (keterampilan), dan penggunaan modal usaha yang relatif sedikit.

Jumlah pelaku bisnis UMKM di Kecamatan Cibinong mengalami pertumbuhan yang sangat signifikan setiap tahunnya. Pada saat ini jumlah UMKM di kecamatan cibinong yang terdaftar di Dinas Koperasi dan UMKM Kabupaten Bogor terdapat 904 unit UMKM yang merupakan gabungan dari keseluruhan jenis sektor usaha, seperti makanan dan minuman, handkraf, konveksi, dan meubel. Banyaknya pelaku usaha dalam jenis usaha yang sama membuat para pelaku usaha saling berlomba-lomba dalam merebut pangsa pasar. Salah satu usaha yang berkembang saat ini adalah usaha bidang kuliner. Usaha dalam bidang kuliner kini mengalami perberkembang yang cukup signifikan. Usaha kuliner mempunyai beraneka ragam jenis, seperti makanan berat dan makanan ringan. Makanan berat atau biasa disebut makanan menu utama adalah makanan yang membuat perut kita kenyang seperti nasi dan lauknya, gado-gado, bakso, mie ayam, dan lain sebagainya. Sedangkan makanan ringan adalah makanan yang bukan merupakan menu utama, makanan ringan biasa disebut cemilan atau kudapan untuk mengganjal perut sementara waktu, seperti keripik, snack, kue basah atau kering, dan lain sebagainya. Saat ini sudah banyak makanan ringan yang beredar di Kecamatan Cibinong yang mempunyai bentuk, rasa, pengemasan, dan tampilan yang berbeda-beda yang dibuat semenarik mungkin untuk menarik 
perhatian konsumen.

Pada saat terjun langsung ke lapangan banyak UMKM yang sudah tidak aktif maupun pindah ke wilayah lain, sehingga dapat disimpulkan bahwa jumlah UMKM di Kecamatan Cibinong tidak sampai 904 unit yang benar-benar aktif. Pada penelitian ini sampel yang digunakan sebanyak 50 responden dengan kriteria UMKM bergerak di bidang usaha makanan ringan. Pemilihan responden dengan kategori makanan ringan karena pada wilayah Kecamatan Cibinong banyak usaha bergerak dibidang makanan ringan.

Pada saat turun ke lapangan untuk melakukan penyebaran kuesioner, cukup banyak yang tidak ingin untuk dijadikan sampel dalam penelitian ini sehingga cukup menyulitkan dalam mendapatkan responden, selain itu cukup banyak juga responden yang tidak mau mengisi kuesioner sendiri sehingga peneliti harus membantunya dalam membacakan pertanyaan serta pilihan pada jawaban kuesioner tersebut.

\section{Deskripsi Data Responden}

Untuk memberikan gambarkan deskripsi data responden menurut usia dan jenis kelamin. Maka di dalam penelitian ini penulis mengambil responden pada pelaku usaha UMKM makanan di Kecamatan Cibinong dengan jumlah 50 orang.

Pertama, responden berdasarkan tingkatan usia dikelompokan menjadi 4 kategori yaitu: usia 21-27 tahun sebanyak 17 orang (34\%), usia 28-34 tahun sebanyak 21 orang (42\%), usia 34-40 tahun sebanyak 7 orang $(14 \%)$ dan di atas 40 tahun sebanyak 5 orang $(10 \%)$. Kedua, responden berdasarkan jenis kelamin laki-laki sebanyak 17 orang (34\%), responden berjenis kelamin perempuan sebanyak 33 orang (66\%). Ketiga, responden berdasarkan omset penjualan dibawah Rp100.000.000 pertahun sebanyak 50 orang $(100 \%)$, responden yang memiliki omset penjualan diatas Rp100.000.000 pertahun sebanyak 0 orang (0\%).

\section{Model Pengukuran (Outer Model)}

Hasil uji validitas diskriminan dengan menggunakan SmartPLS 3.0. Diagram jalur yang terbentuk adalah sebagai berikut:

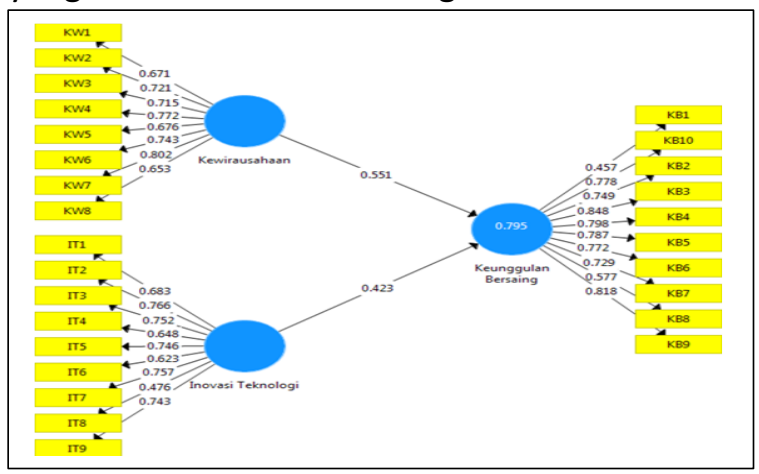

Gambar 4. Nilai Loading Faktor Outer Model

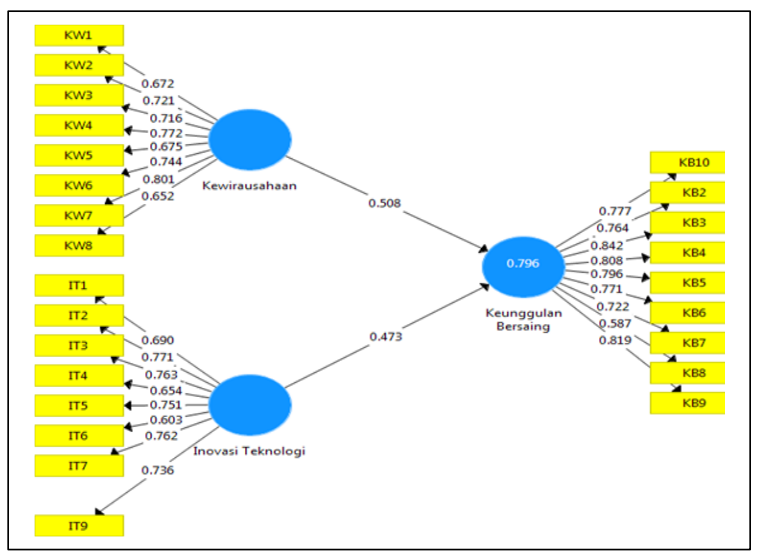

Gambar 5. Nilai Loading Faktor Outer Model setelah Reestimasi

Berdasarkan hasil dari perhitungan ulang atau re-estimasi, dapat disimpulkan bahwa semua instrument dari indikator mengenai variabel telah memenuhi syarat dan dinyatakan valid karena semua nilai korelasi memiliki nilai factor loading $>0,50$

\section{Uji Hipotesis}

\section{Tabel 1. Average Variance Extracted (AVE)}

\begin{tabular}{lc}
\hline & $\begin{array}{c}\text { Average Variance } \\
\text { Extracted (AVE) }\end{array}$ \\
\hline Kewirausahaan (X1) & 0,519 \\
\hline Inovasi Teknologi (X2) & 0,516 \\
\hline Keunggulan Bersaing (Y) & 0,590 \\
\hline
\end{tabular}




\section{Sumber: Hasil Output Smart-PLS 3.0}

Tabel 1 di atas menunjukkan nilai Average Variance Extracted (AVE) di atas 0,5 untuk semua variabel yang terdapat pada model penelitian Maka dapat disimpulkan bahwa variabel kewirausahaan, inovasi teknologi, dan keunggulan bersaing adalah valid.

\section{Uji Reliabilitas}

Hasil output Smart-PLS 3.0 didapatkan nilai Composite Reliability dan Cronbach's Alpha masing-masing variabel konstruk sebagai berikut:

Tabel 2. Uji Reliabilitas

\begin{tabular}{lcc}
\hline & $\begin{array}{c}\text { Composite } \\
\text { Reliability }\end{array}$ & $\begin{array}{c}\text { Cronbach's } \\
\text { Alpha }\end{array}$ \\
\hline Kewirausahaan $(\mathrm{X} 1)$ & 0,896 & 0,868 \\
\hline Inovasi Teknologi $(\mathrm{X} 2)$ & 0,895 & 0,865 \\
\hline Keunggulan Bersaing $(\mathrm{Y})$ & 0,928 & 0,912 \\
\hline
\end{tabular}

Sumber: Hasil Output Smart-PLS 3.0

Pada Tabel 2 di atas, hasil output composite reliability menunjukkan bahwa nilai composite reliability untuk semua variabel adalah di atas 0,7 yang menunjukkan bahwa semua variabel pada model yang diestimasi memenuhi kriteria.

Uji reliabilitas juga bisa diperkuat oleh hasil Cronbach's Alpha, di mana pada Tabel 2 di atas hasil output Cronbach's Alpha pada masing-masing variabel memiliki nilai $>0,7$. Hal ini menunjukkan bahwa semua variabel memiliki tingkat sangat reliabel terhadap masing-masing konstruknya karena memiliki nilai $>0,80-1,00$ pada tabel tingkat reliabilitas.

\section{Uji t-Statistik}

Uji t statistik atau uji parsial pada dasarnya digunakan untuk mengetahui ada atau tidaknya pengaruh variabel penjelas/independen terhadap variabel terikat/dependen. Pada penelitian ini adalah untuk mengetahui ada atau tidaknya pengaruh signifikan antara kewirausahaan (X1) dan inovasi teknologi (X2) terhadap keunggulan bersaing $(\mathrm{Y})$. Untuk mencari nilai $\mathrm{t}$ tabel dilihat dari taraf signifikansi 0,05 dimana $\mathrm{df}=$ jumlah sampel - jumlah variabel. Maka diketahui $t$ tabel $=2,012$ yang diperoleh dari rumus $\mathrm{df}=\mathrm{N}$ $\mathrm{K}$ atau $\mathrm{df}=50-3=47$, kemudian dihubungkan dengan derajat kepercayaan $95 \%$ dan derajat kesalahan $5 \%$ atau 0,05 . Berdasarkan hasil pengolahan data untuk uji signifikansi (Uji t) pada software Smart-PLS 3.0, diperoleh hasil sebagai berikut:

Tabel 3. Hasil Nilai Koefisiensi Analisis Jalur

\begin{tabular}{lccc}
\hline & $\begin{array}{c}\text { Original } \\
\text { Sample }(\mathrm{O})\end{array}$ & $\begin{array}{c}\text { T Statistik } \\
(|\mathrm{O} / \mathrm{STDEV}|)\end{array}$ & $\begin{array}{c}\mathrm{P} \\
\text { Values }\end{array}$ \\
\hline $\begin{array}{l}\text { Kewirausahaan }(\mathrm{X} 1)- \\
\text { >Keunggulan Bersaing }(\mathrm{Y})\end{array}$ & 0,508 & 4,312 & 0,000 \\
\hline $\begin{array}{l}\text { Inovasi Teknologi }(\mathrm{X} 2)- \\
\text { >Keunggulan Bersaing }(\mathrm{Y})\end{array}$ & 0,473 & 4,665 & 0,000 \\
\hline
\end{tabular}

Sumber: Hasil Output Smart-PLS 3.0

Hasil pengujian pengaruh variabel kewirausahaan terhadap keunggulan bersaing menunjukan nilai korelasi sebesar 0,508 artinya variabel kewirausahaan memiliki hubungan yang positif terhadap keunggulan bersaing. Dan memiliki nilai $t_{\text {hitung }} 4,312>t_{\text {tabel }} 2,012$ serta nilai signifikan sebesar $0,00<0,05$. Hal ini menunjukan hasil bahwa kewirausahaan berpengaruh positif secara signifikan terhadap keunggulan bersaing.

Hasil pengujian pengaruh variabel inovasi teknologi terhadap keunggulan bersaing menunjukan nilai korelasi sebesar 0,473 artinya variabel inovasi teknologi memiliki hubungan yang positif terhadap keunggulan bersaing. Dan memiliki nilai $t_{\text {hitung }} 4,665>t_{\text {tabel }} 2,012$ serta nilai signifikan sebesar $0,000<0,05$. Hal ini menunjukkan hasil bahwa inovasi teknologi berpengaruh positif secara signifikan terhadap keunggulan bersaing.

\section{R Square}

$\mathrm{R}$ Square menggambarkan kemampuan model menjelaskan variasi yang terjadi dalam variabel dependen. Hasil output software Smart-PLS 3.0 terkait uji R Square diperoleh 
nilai $\mathrm{R}$ Square keunggulan bersaing sebesar 0,796 . Hal ini menunjukkan bahwa kontribusi variabel kewirausahaan dan inovasi teknologi terhadap keunggulan bersaing sebesar $79,6 \%$ dan sisanya sebesar 20,4\% dipengaruhi oleh variabel lain, seperti orientasi pasar, orientasi pelanggan, dan lain sebagainya di luar penelitian ini.

\section{Q-Square}

Untuk menguji model struktural (inner model) penelitian juga dapat melalui uji QSquare predictive relevance yang digunakan untuk mengukur seberapa baik nilai observasi dihasilkan oleh model dan juga estimasi parameternya. Maka dapat dilihat nilai $\mathrm{Q}^{2}$ dalam penelitian ini adalah $Q^{2}=1-\left(1-R 1^{2}\right)=$ $\mathbf{0 , 7 9 6}$. Hal ini sesuai dengan ketentuan bahwa besaran $Q^{2}$ memiliki nilai rentang $0<Q^{2}<1$, di mana semakin mendekati 1 berarti model semakin baik. Sehingga $0<\mathbf{0 , 7 9 6}<1$, dapat disimpulkan bahwa model penelitian ini adalah baik.

\section{Pembahasan}

Dari hasil penelitian mengenai kewirausahaan dan inovasi teknologi terhadap keunggulan bersaing dengan menggunakan metode Partial Least Square (PLS) dengan Software Smart-PLS 3.0 diperoleh hasil sebagai berikut:

\section{Pengaruh Kewirausahaan Terhadap Keunggulan Bersaing}

Berdasarkan hasil penelitian ini, bahwa pengujian hipotesis menunjukan nilai korelasi sebesar 0,508 dan uji t-statistik menunjukan nilai $t_{\text {hitung }} 4,312>t_{\text {tabel }} 2,012$ serta nilai signifikan sebesar 0,000 $<0,050$ yang artinya bahwa kewirausahaan berpengaruh secara positif terhadap keunggulan bersaing. Berdasarkan hasil penelitian diketahui bahwa kontribusi terbesar pada kewirausahaan yaitu pada pekanya pelaku usaha terhadap perubahan permintaan konsumen sehingga membuat konsumen merasa terpenuhi kebutuhan dan keinginannya. Dari hal tersebut maka akan terciptanya keunggulan terhadap produk tersebut.

Dapat disimpulkan hasil penelitian ini sesuai dengan hipotesis yang telah diusulkan peneliti bahwa kewirausahaan berpengaruh signifikan terhadap keunggulan bersaing. Hasil penelitian ini sejalan dengan Paulus \& Wardhani (2018) yang menyatakan bahwa kewirausahaan berpengaruh signifikan terhadap keunggulan bersaing. Hal tersebut sama dengan hasil penelitian dari Djodjobo \& Tawas (2014) yang menyatakan bahwa kewirausahaan berpengaruh signifikan terhadap keunggulan bersaing.

\section{Pengaruh Inovasi Teknologi terhadap Keunggulan Bersaing}

Berdasarkan hasil penelitian ini, bahwa pengujian hipotesis menunjukan nilai korelasi sebesar 0,473 dan uji t-statistik menunjukan nilai $t_{\text {hitung }} 4,665>t_{\text {tabel }} 2,012$ serta nilai signifikan sebesar $0,000<0,050$ yang artinya bahwa inovasi teknologi berpengaruh secara signifikan terhadap keunggulan bersaing. Berdasarkan hasil penelitian diketahui bahwa kontribusi terbesar pada inovasi teknologi yaitu berada pada pemanfaatan media sosial untuk melakukan promosi penjualan, sehingga dengan aktifnya para pelaku usaha dalam menggunakan dan memanfaatkan media sosial membuat konsumen semakin mengenal dan tertarik pada produk makanan ringan produk UMKM.

Dapat disimpulkan hasil penelitian ini sesuai dengan hipotesis yang telah diusulkan peneliti bahwa inovasi teknologi berpengaruh terhadap keunggulan bersaing. Hasil penelitian ini sejalan dengan Muthaher \& Assegaf (2014) menyatakan bahwa inovasi teknologi berpengaruh signifikan terhadap keunggulan bersaing.

\section{PENUTUP}

Berdasarkan hasil serangkaian penelitian serta uji hipotesis yang telah dilakukan melalui analisis Partial Least Square (PLS) mengenai 
Luhung Bagas Prayogo: Pengaruh Kewirausahaan ...

pengaruh kewirausahaan dan inovasi teknologi terhadap keunggulan bersaing UMKM makanan di Kecamatan Cibinong, maka dapat disimpulkan bahwa pertama, variabel kewirausahaan berpengaruh signifikan terhadap keunggulan bersaing UMKM makanan di Kecamatan Cibinong. Artinya, para pelaku usaha peka terhadap perubahan permintaan konsumen sehingga konsumen merasa terpenuhi kebutuhan dan keinginannya. Kedua, variabel inovasi teknologi berpengaruh signifikan terhadap keunggulan bersaing UMKM makanan di Kecamatan Cibinong. Artinya, dengan pemanfaatan media sosial untuk melakukan promosi penjualan membuat konsumen semakin mengenal produk dan tertarik pada produk tersebut.

\section{REFERENSI}

Anggiani, S. (2018). Kewirausahaan: Pola Pikir, Pengetahuan, Keterampilan (2 ed.). Jakarta: Prenadamedia Group.

Anwar, M. (2014). Pengantar Kewirausahaan Teori Dan Aplikasi (1 ed.). Jakarta, Prenadamedia Group.

Aziz, N. N., \& Samad, S. (2016). Innovation and Competitive Advantage: Moderating Effects of Firm Age in Foods Manufacturing SMEs in Malaysia. 256266.

Badan Pusat Statistik Kabupaten Bogor. (2019). Data Pertumbuhan Ekonomi Kabupaten Bogor

Chandra, A., Soegiono, \& Sugiarto. (2016). Analisis Pengaruh Teknologi Dan Rantai Nilai Dalam Pencapaian Keunggulan Bersaing Berkelanjutan Dalam Upaya Peningkatan Kinerja Usaha Di Industri Kulit Manding Yogyakarta. Diponegoro Journal Of Management, 1-12.

Dhewanto, W., Mulyaningsih, H. D., Permatasari, A., Anggadwita, G., \& Ameka, (2014). Manajemen Inovasi Peluang Sukses Menghadapi Perubahan, Yogyakarta: CV Andi Offset.

Dinas Koperasi dan UMKM Kabupaten Bogor. (2019). Data Jumlah UKM Kecamatan
Cibinong

Djodjobo, C. V., \& Tawas, H. N. (2014). Pengaruh Kewirausahaan, Inovasi Produk, Dan Keunggulan Bersaing Terhadap Kinerja Pemasaran Usaha Nasi Kuning Di Kota Manado. Jurnal EMBA, 2.

Echdar, S. (2013). Manajemen Entrepreneurship Kiat Sukses Menjadi Wirausaha.

Yogyakarta: CV Andi Offset.

Ferdinand, A. (2014). Metode Penelitian Manajemen (5 ed.). Semarang: Badan Penerbit Universitas Diponogoro.

Ghozali, I. (2014). Structural Equation Modeling Metode Alternatif Dengan Partial Least Squares (PLS). Semarang: Badan Penerbit Universitas Diponogoro.

Ghozali, I. (2016). Aplikasi Analisis Multivariate Dengan Program IBM SPSS23.

Semarang: Badan Penerbit Universitas Diponogoro.

Hasan, S. (2014). Manajemen Strategik (1 ed.). Jakarta: Global Future Institute. Hendro. (2011). Dasar-Dasar Kewirausahaan: Panduan Bagi Mahasiswa Untuk Mengenal, Memahami, Dan Memasuki Dunia Bisnis. Jakarta: Erlangga.

Kotler, P., \& Keller, K. L. (2016). Marketing Management (15th ed.). Harlow: Pearson Education Limited.

Kurniawan. (2014). Total Marketing. Yogyakarta: Kobis.

Muthaher, O., \& Assegaf, M. (2014). Model Pengembangan Inovasi Teknologi Dan Kelembagaan Kemitraan Rantai Pasok Guna Meningkatkan Daya Saing UKM. EKOBIS, 62-73.

Nasution, A. H., \& Kartajaya, H. (2014). Inovasi (1 ed.). Yogyakarta: CV Andi Offset.

Paulus, L. B., \& Wardhani, Z. K. (2018). Keunggulan Bersaing Usaha Cake Dan Bakery: Peran Orientasi Pasar, Orientasi Kewirausahaan, Dan Inovasi Produk. Jurnal Manajemen.

Pearce, J. A., \& Robinson, R. B. (2013). Strategic Management: Formulation, Implementation, And Control (12 ed.). 
(N. P. Sari, Penerj.) Jakarta: Salemba Empat.

Pertumbuhan ekonomi Kabupaten Bogor meningkat. Diakses pada 25 Februari 2019, dari https://megapolitan.antaranews.com/b erita/49194/pertumbuhan-ekonomikabupaten-bogor-meningkat

Quantananda, E., \& Haryadi, B. (2015). Pengaruh Orientasi Kewirausahaan Pada Perusahaan Makanan Dan Minuman Di Surabaya. AGORA, 3.

Robbins, S. P., \& Coulter, M. (2016). Manajemen (13 ed.). (B. Sabran, \& D. B. Putera, Penerj.) Jakarta: Erlangga.

Sarjono, H., \& Julianta, W. (2011). SPSS VS Lisrel Sebuah Pengantar Aplikasi Untuk Riset. Jakarta: Salemba Empat.

Setiawan, H. (2012). Pengaruh Orientasi Pasar, Orientasi Teknologi Dan Inovasi Produk Terhadap Keungguan Bersaing Usaha Songket Skala Kecil Di Kota Palembang. Jurnal Orasi Bisnis(ISSN: 2085-1375).

Sugiyono. (2017). Metode Penelitian
Kuantitatif, Kualitatif, Dan R\&D. Bandung: Alfabeta.

Suryana. (2013). Ekonomi Kreatif (Ekonomi Baru: Mengubah Ide dan Menciptakan Peluang). Jakarta: Salemba Empat.

Suryana, Y., \& Bayu, K. (2013). Kewirausahaan Pendekatan Karakteristik Wirausaha Sukses (2 ed.). Jakarta: Kencana Prenada Media Grup.

Tambunan, T. (2012). Usaha Mikro Kecil dan Menengah Di Indonesia (1 ed.). Jakarta: LP3ES.

Wilantara, R. F., \& Susilawati. (2016). Strategi \& Kebijakan Pengembangan UMKM (1 ed.). Bandung: PT Refika Aditama.

Yuliana, A., Mahfudnurnajamuddin, Sufri, \& Serang, S. (2017). Influence Of Product Innovation To The Advantages of Competitive In SME Processing Seawed Through Performance, Marketing In West Beach Area, South Sulawesi Provinc. International Journal Of Science And Research (IJSR).Vol 7 No 4 Hal 795. 
